\title{
Concentration and detection of salmonid alphavirus in seawater during a post-smolt salmon (Salmo salar) cohabitant challenge
}

\author{
Lisa-Victoria Bernhardt ${ }^{1, *}$, Mette Myrmel ${ }^{2}$, Atle Lillehaug ${ }^{1}$, Lars Qviller ${ }^{1}$, \\ Simon Chioma Weli ${ }^{1}$
}

\author{
${ }^{1}$ Norwegian Veterinary Institute, PO Box 750 Sentrum, 0106 Oslo, Norway \\ ${ }^{2}$ Norwegian University of Life Sciences, Faculty of Veterinary Medicine, Virology Unit, PO Box 8146 Dep., \\ 0033 Oslo, Norway
}

\begin{abstract}
Currently, the prevalence of salmonid alphavirus (SAV) in Norwegian Atlantic salmon farms is largely surveyed via sacrificing fish and sampling of organ tissue on a monthly basis. However, a more cost-efficient, straightforward, rapid, reliable, reproducible and animal welfare friendly method based on the detection of SAV in water could be considered as an alternative method. In the present study, such a method was developed and optimized through a 6 wk cohabitant challenge trial, using post-smolt Atlantic salmon Salmo salar L challenged with high or low doses of SAV subtype 3 (SAV3). Tank water and tissue samples from cohabitant fish were collected at 16 time points. SAV3 was concentrated from the water by filtration, using either electronegative or electropositive membrane filters, which were subsequently rinsed with one of 4 different buffer solutions. SAV3 was detected first in tank water ( $7 \mathrm{~d}$ post-challenge, DPC), and later in cohabitant fish organ tissue samples (12 DPC). The electronegative filter (MF-Millipore ${ }^{\mathrm{TM}}$ ) and rinsing with NucliSENS ${ }^{\circledR}$ easyMAG ${ }^{\circledR}$ Lysis Buffer presented the best SAV3 recovery. A significant positive correlation was found between SAV3 in the tank water concentrates and the midkidney samples. Based on these results, detection of SAV3 in filtrated seawater is believed to have the potential to serve as an alternative method for surveillance of SAV in Atlantic salmon farms.
\end{abstract}

KEY WORDS: SAV detection - SAV concentration · Water filtration · Surveillance - RT-qPCR · Membrane filters $\cdot$ Salmonid alphavirus $\cdot$ Pancreas disease

\section{INTRODUCTION}

Pancreas disease (PD) is considered to be one of the most serious virus diseases in sea-farmed salmonids (Sommerset et al. 2020), resulting in significant economic consequences (Jansen et al. 2015). PD was discovered for the first time in 1976 in Scotland (Munro et al. 1984) and first reported in Norway more than a decade later (Poppe et al. 1989). The aetiological agent for PD was first reported in 1995 (Nelson et al. 1995) and is described as an enveloped, positive-sense single-stranded RNA virus (+ssRNA)

*Corresponding author: lisa-victoria.bernhardt@vetinst.no

$\S_{\text {Corrections were made after publication. For details see }}$ www.int-res.com/articles/dao_oa/d146p065.pdf

This corrected version: September 23, 2021
(Deperasińska et al. 2018), formally named Salmonid alphavirus (SAV) (Weston et al. 2002).

SAV belongs to the genus Alphavirus in the family Togaviridae (Nelson et al. 1995, Weston et al. 2002) and, based on phylogenetic analysis of the partial E2 gene and nsP3 gene in SAV from farmed Atlantic salmon Salmo salar L. and rainbow trout Oncorhynchus mykiss, this virus can be divided into 6 subtypes (i.e. SAV1-SAV6) (Fringuelli et al. 2008). In Norway, there are currently 2 known subtypes (SAV2 and SAV3), and they are primarily distributed into 2 different PD endemic zones (Hjortaas et al. 2016). SAV3

(C) The authors 2021. Open Access under Creative Commons by Attribution Licence. Use, distribution and reproduction are unrestricted. Authors and original publication must be credited. 
has so far only been found in Norway, in aquaculture of rainbow trout and Atlantic salmon (Hodneland et al. 2005).

Various experimental challenge studies have shown that SAV spreads via horizontal transmission (McLoughlin et al. 1996, Andersen et al. 2010, Xu et al. 2012, Graham et al. 2012, Jarungsriapisit et al. $2016 a, b, 2020)$. In some of these studies it was also possible to detect SAV directly from seawater (Andersen et al. 2010, Jarungsriapisit et al. 2016a,b, 2020). However, the current methods for detection of SAV and diagnosis of PD involve sampling of fish, followed by histopathology and quantitative realtime PCR (RT-qPCR). In 2007, PD became a notifiable fish disease (list 3) in Norway. National regulation was introduced in order to reduce the consequences of PD in a defined PD zone and to prevent further spread of SAV. Revision of the regulations in 2017 introduced different control zones for SAV2 and SAV3, as well as a surveillance zone.

The surveillance programme requires monthly sampling for PCR analysis of Atlantic salmon, trout, rainbow trout and char from all marine operative fish farming sites without current status as SAV-infected (Lovdata 2017). This results in the sacrifice of thousands of fish every year and is a time-consuming and resource-demanding approach that relies on analysing a relatively small number of fish that should represent the whole population on a site. Hence, in the beginning of an outbreak, when few individuals are infected, the likelihood of identifying the infected fish is small. A water sample that represents the environment for the total population in the farm may therefore serve a possible alternative due to fish shedding SAV into the water. Monitoring of the aquatic environment for harmful pathogens by filtration of water has been found to be successful, as reported for the oomycete Aphanomyces astaci which causes the crayfish plague (Strand et al. 2019, Rusch et al. 2020) and for the fish ectoparasite Gyrodactylus salaris (Rusch et al. 2018), and constitutes an animal welfare friendly method, with a potential for improved management strategies.

It has been reported that filtering water through charged membrane filters is a useful tool for concentrating viruses from water (Cashdollar \& Wymer 2013). This simple and efficient technique is known as virus adsorption-elution (viradel), and has been described in several studies (Wallis et al. 1972, Farrah et al. 1976, Goyal \& Gerba 1983), including SAV challenge trials (Andersen et al. 2010, Jarungsriapisit et al. 2016a,b, 2020). Recently, we carried out an in vitro study involving filtration of artificial and natural seawater that was spiked with SAV3 (Weli et al. 2021). Virus in water samples was concentrated by adsorption to either electronegative or electropositive membrane filters, followed by rinsing of filters with one of 4 different buffer solutions, and quantifying using RT-qPCR and reverse-transcription droplet digital PCR (RT-ddPCR).

In the present study, our aim was to evaluate the potential of these 5 methods in detecting SAV3 directly from seawater holding infected post-smolt Atlantic salmon. Therefore, a 6 wk cohabitant challenge study was performed, with sampling of tank water and fish tissue at 16 time points. An efficient concentration method (CM) for SAV in water may serve as a cost-efficient, straightforward, rapid, reliable and reproducible process for detection of SAV in Atlantic salmon farms compared to screening of fish. Such a method may result in earlier identification of infection in a fish population and prevention of further virus spread. This method may also be developed for other waterborne pathogenic viruses, thus enabling earlier disease control measures and improved virological safety of the water environment.

\section{MATERIALS AND METHODS}

\subsection{Experimental design}

A cohabitant challenge trial was carried out in 3 separate tanks for a duration of $38 \mathrm{~d}$. The number of shedder fish and cohabitant fish in each tank was 15 and 55, respectively. During the challenge period, sampling of both tank water and cohabitant fish was performed at 16 time points (see Fig. 1).

\subsection{Experimental fish}

The Atlantic salmon used in this trial arrived as eyed eggs when they were approximately 370 degreedays and were reared at the fish facility at the Industrial and Aquatic Laboratory (ILAB, Bergen High Technology Centre). In total, 210 post-smolts of Atlantic salmon of strain Stofnfiskur Iceland (SF Optimal), with an average weight of $110.9 \mathrm{~g}$, were used in the challenge, which took place approximately 1 yr after hatching. The fish were unvaccinated and pre-screened (at 5 and $15 \mathrm{~g}$ of size) and tested negative for SAV, infectious salmon anaemia virus (ISAV), infectious pancreatic necrosis virus (IPNV), piscine myocarditis virus (PMCV), piscine orthoreovirus (PRV) and salmon gill poxvirus (SGPV). 
Parent fish were pre-screened for the equivalent, apart from SGPV.

\subsection{SAV3 inoculum}

The SAV3 originated from pooled heart and head kidney samples of Atlantic salmon from the Hordaland region of Norway (Taksdal et al. 2015). Propagation of SAV3 was performed using the CHSE-214 cell line (ATCC ${ }^{\circledR}$ CRL-1681 ${ }^{\mathrm{TM}}$ ), which was derived from a Chinook salmon Oncorhynchus tshawytscha embryo. These cells were grown on L-15 (Leibowitz) medium (Lonza), supplemented with $10 \%$ fetal bovine serum (FBS) and gentamicin at $20^{\circ} \mathrm{C}$. Serial 10 fold dilutions of the SAV3 stock (passage number 4) were inoculated onto $24 \mathrm{~h}$ old CHSE- 24 monolayers in 96 well plates, allowing quantification. The viral endpoint titre, measured as $50 \%$ tissue culture infective dose $\left(\mathrm{TCID}_{50}\right)$, was determined to be $10^{6}$ $\mathrm{TCID}_{50} \mathrm{ml}^{-1}$ as described by Reed \& Muench (1938).

\subsection{Experimental tanks}

Three identical 5001 seawater tanks were used in the challenge trial, designated $T_{L}, T_{H}$ and $T_{C}$ for low viral dose, high viral dose and negative control tank, respectively. The seawater originated from $105 \mathrm{~m}$ depth from Byfjorden and had been filtered through $20 \mu \mathrm{m}$ drum filters and treated with UV light $(135 \mathrm{~W}$ $\mathrm{m}^{-2}$ ). The water flow in all tanks was the same throughout the experiment, with an average flow rate of $950 \mathrm{l} \mathrm{h}^{-1} \operatorname{tank}^{-1}$ and was set according to the biomass, dissolved oxygen level and tank water temperature in order to meet an optimal oxygen level for the fish. Water was monitored daily for temperature, salinity and dissolved oxygen levels throughout the challenge. During the challenge period in $\mathrm{T}_{\mathrm{L}}, \mathrm{T}_{\mathrm{H}}$ and $\mathrm{T}_{\mathrm{C}}$, respectively, the following variations were seen; dissolved oxygen ranged between 79-97, 80-97 and $79-86 \%$, tank water temperatures between $11.7-$ $12.3,11.7-12.3$ and $11.5-12.4^{\circ} \mathrm{C}$, and salinity levels between 34.1-34.5, 34.1-34.5 and 34.2-34.5\%.

All tanks had a daily photoperiod of $12 \mathrm{~h}$ light:12 h dark, provided by an automatic artificial lighting system. During the $12 \mathrm{~h}$ of light, an automatic feeder dispenser fed the fish with $3 \mathrm{~mm}$ Nutra Olympic pellets (Skretting). The amount of food given in $\mathrm{T}_{\mathrm{C}}$ was between 80-150 $\mathrm{g}_{\text {; }}$ in $\mathrm{T}_{\mathrm{L}}$, between 56-140 $\mathrm{g}_{\text {; }}$ and in $\mathrm{T}_{\mathrm{H}}$, between 56-140 $\mathrm{g}_{\text {; }}$ amounts were adjusted marginally as the fish were growing, dying or being sampled.
Clinical signs in the fish, as well as mortality, were monitored daily in all 3 tanks. Dead experimental fish were removed daily and did not undergo any further analysis.

\subsection{Challenge}

A total of 45 fish (shedder fish) were immersed into a bath with the anaesthetic Finquel ${ }^{\circledR}$ vet. $1000 \mathrm{mg} \mathrm{g}^{-1}$ $\left(100 \mathrm{mg} \mathrm{l}^{-1}\right)$. Once immobilized, each shedder fish was administered with $0.2 \mathrm{ml}$ inoculum by intraperitoneal (i.p.) injection of either a low SAV3 dose of $2 \times$ $10^{2} \mathrm{TCID}_{50} \mathrm{fish}^{-1}$, a high SAV3 dose of $2 \times 10^{4} \mathrm{TCID}_{50}$ fish $^{-1}$ or virus-free Leibovitz-15 (L-15) cell culture medium containing $2 \%$ FBS (mock inoculum). All shedder fish were marked by adipose fin clipping, which allowed us to distinguish them from cohabitant fish. Each group of 15 shedder fish was then transferred into the respective 5001 seawater tank $\left(T_{L}, T_{H}\right.$ and $\mathrm{T}_{\mathrm{C}}$ ) containing 55 cohabitant fish which had been transferred into the tanks $2 \mathrm{~d}$ earlier $(-2 \mathrm{~d}$ post-challenge, DPC). The shedder fish remained in the tanks throughout the entire challenge period. The challenge was performed and approved in accordance with the Norwegian Animal Research Authority (NARA).

\subsection{Sampling}

Sampling of tank water and cohabitant fish was performed at 16 different time points: $0,7,12,16,19,20$, $21,22,23,24,25,28,29,30,33$ and 37 DPC. Water sampling was carried out by using sterilized $1000 \mathrm{ml}$ Borosilicate 3.3 glass bottles (VWR ${ }^{\circledR}$ ) that were submerged by hand to approximately $15 \mathrm{~cm}$ below the water surface with the mouth of the bottle turned towards the water current. Five 11 water samples were taken from each of the 3 tanks at each sampling time point. $T_{C}$ was sampled first, followed by $\mathrm{T}_{\mathrm{L}}$ and lastly $\mathrm{T}_{\mathrm{H}}$.

Three fish were randomly collected from each of $T_{L}$ and $\mathrm{T}_{\mathrm{H}}$, and one fish was collected from $\mathrm{T}_{\mathrm{C}}$ at each sampling point. Sampled fish were euthanized through an immersion bath with an overdose of Finquel ${ }^{\circledR}$ vet. $1000 \mathrm{mg} \mathrm{g}^{-1}\left(150 \mathrm{mg} \mathrm{l}^{-1}\right)$. Gross pathology was evaluated, and tissue samples were collected from heart (including the valves and bulbus arteriosus) and mid-kidney for RT-qPCR (stored in RNAlater ${ }^{\mathrm{TM}}$ Soln. [Thermo Fisher Scientific Baltics], at room temperature) and heart and pancreas (pyloric caeca with attached pancreatic tissue) for histopathology (stored in 10\% neutral buffered formalin, at room temperature). 


\subsection{Histopathology}

Histopathological examination was performed with a light microscope on pancreas and heart tissue samples from cohabitant fish, identified as SAV3positive by RT-qPCR, in order to confirm SAV infection and PD. The tissue samples were fixed in $10 \%$ neutral buffered formalin and processed according to standard procedures at the Norwegian Veterinary Institute in Oslo (NVI, Oslo).

\subsection{Concentration of SAV3 from tank water samples}

Concentration of SAV3 from 11 water samples from each of the 3 water tanks was performed according to 5 CMs, previously developed by Weli et al. (2021). Briefly, the methods involved filtration of 11 tank water through either an electropositive or an electronegative membrane filter, followed by elution of the adsorbed material from the filter with one of 4 different buffer solutions (buffer 1-4). An overview of the 5 filter/buffer combinations is given in Table 1. Filters were then inserted into a $47 \mathrm{~mm}$ in-line filter holder (Merck Millipore) fitted to a Masterflex ${ }^{\circledR}$ portable environmental sampler pump (Cole-Parmer Instrument Company). Following filtration of the water sample, the filter was rinsed using a buffer solution.

For the methods using buffer 1, the intact filter was rinsed in a $50 \mathrm{~mm}$ Petri dish with $2.4 \mathrm{ml}$ buffer 1 and subsequently shaken on an orbital shaker at $600 \mathrm{rpm}$ for $30 \mathrm{~min}$. For the 3 other buffer solutions, the filter was cut into $<1 \mathrm{~cm}^{2}$ fragments and transferred into a $50 \mathrm{ml}$ CELLSTAR ${ }^{\circledR}$ tube (Greiner Bio-One) containing $4.0 \mathrm{ml}$ buffer 2, 3 or 4 and subsequently vortexed 3 times for $1 \mathrm{~min}$ with 5 min rests. The eluate (i.e. tank water concentrate) was distributed as $1 \mathrm{ml}$ into
$1.5 \mathrm{ml}$ Eppendorf ${ }^{\circledR}$ SafeSeal tubes (Sarstedt AG \& Co.) and stored at $-80^{\circ} \mathrm{C}$ until RNA extraction.

Tank water from $\mathrm{T}_{\mathrm{C}}$ was filtered first, followed by $\mathrm{T}_{\mathrm{L}}$ and lastly $\mathrm{T}_{\mathrm{H}}$. Hoses and filter heads were disinfected between sampling of each tank by pumping (flow rate $0.21 \mathrm{~min}^{-1}$ ) 11 of $10 \%$ chlorine for $10 \mathrm{~min}$, followed by neutralisation with 11 of $10 \%$ Alfa Aesar sodium thiosulfate pentahydrate, 99+\% (ThermoFisher Scientific) for $10 \mathrm{~min}$ and finally by rinsing with 11 distilled water for $10 \mathrm{~min}$.

\subsection{RNA extraction of tank water concentrates}

One ml NucliSENS ${ }^{\circledR}$ easyMAG ${ }^{\circledR}$ Lysis Buffer (bioMérieux) was added to $1 \mathrm{ml}$ tank water concentrate followed by RNA extraction, using the easyMAG ${ }^{\circledR}$ robot (bioMérieux) and the standard lysis protocol (generic 2.0.1.), which was performed with $50 \mu \mathrm{l}$ magnetic silica beads, according to the NucliSENS easyMAG user manual (bioMérieux 2009). RNA was eluted in $50 \mu \mathrm{l}$ buffer and stored at $-80^{\circ} \mathrm{C}$ until use in RT-qPCR.

\subsection{RNA extraction from organ tissue}

Tissue samples (i.e. heart and mid-kidney) were stored in RNAlater ${ }^{\mathrm{TM}}$ Soln. (Thermo Fisher Scientific Baltics) at $-80^{\circ} \mathrm{C}$ prior to RNA extraction, which was performed by adding approximately $20 \mathrm{mg}$ tissue with $180 \mu \mathrm{l}$ ATL Lysis Buffer (Qiagen ${ }^{\circledR}$ ) and $20 \mu \mathrm{l}$ Proteinase $\mathrm{K}$ and incubation overnight at $56^{\circ} \mathrm{C}$. Extraction was performed with QIAcube ${ }^{\circledR}$ (Qiagen $\left.{ }^{\circledR}\right)$ with the reagents from the DNeasy Blood \& Tissue Kit (Qiagen $\left.{ }^{\circledR}\right)$, giving an RNA elution volume of $200 \mu \mathrm{l}$. Isolated RNA was stored at $-80^{\circ} \mathrm{C}$ until use in RT-qPCR.

Table 1. Overview of the 5 different concentration methods $\left(\mathrm{CM}_{\mathrm{A}-\mathrm{E}}\right)$ used to concentrate salmonid alphavirus subtype 3 (SAV3) from tank water during the cohabitant challenge trial with post-smolt Atlantic salmon. The methods are presented as 5 different combinations of membrane filters and buffer solutions used for SAV3 adsorption and elution, respectively

\begin{tabular}{|c|c|c|c|}
\hline $\begin{array}{l}\text { Concentration } \\
\text { method }\end{array}$ & Filter & $\begin{array}{c}\text { Buffer } \\
\text { no. }\end{array}$ & Buffer solution \\
\hline $\mathrm{CM}_{\mathrm{A}}$ & Electronegative $^{\mathrm{a}}$ & 1 & Lysis buffer ${ }^{\mathrm{C}}$ \\
\hline $\mathrm{CM}_{\mathrm{B}}$ & Electropositive $^{\mathrm{b}}$ & 1 & Lysis buffer ${ }^{\mathrm{C}}$ \\
\hline $\mathrm{CM}_{\mathrm{C}}$ & Electronegative $^{\mathrm{a}}$ & 2 & $1 \mathrm{mM} \mathrm{NaOH}^{\mathrm{d}}(\mathrm{pH} 9.5)$ \\
\hline $\mathrm{CM}_{\mathrm{D}}$ & Electronegative $^{a}$ & 3 & $\mathrm{~L}-15$ medium $^{\mathrm{e}}(\mathrm{pH} 9.0)+2 \%$ FBS \\
\hline $\mathrm{CM}_{\mathrm{E}}$ & Electropositive $^{\mathrm{b}}$ & 4 & L-15 medium ${ }^{\mathrm{e}}(\mathrm{pH} 7.3-7.75)+2 \%$ FBS \\
\hline
\end{tabular}




\subsection{RT-qPCR}

The SAV3 strain was detected using the Q_nsP1 assay (Hodneland \& Endresen 2006). This broadspectrum assay detects all known SAV subtypes using primers and probe with final concentrations of 500 and $300 \mathrm{nM}$, respectively and amplifies a conserved region in the 5' end of the Q_nsP1-gene, giving amplicons of $107 \mathrm{bp}$ (Table 2).

Extracted RNA was automatically pipetted by Eppendorf epMotion ${ }^{\circledR} 5075$ (Eppendorf) in duplicates, analyzed by RT-qPCR on an AriaMx machine (Agilent Technologies) and evaluated with the Agilent AriaMx Real-Time PCR software (version 1.7). Each plate included a negative control sample and an inter plate calibrator of pure SAV3 RNA, which were both run in duplicates.

The cut-off quantification cycle $(\mathrm{Cq})$ value was set to 40 ; samples with values below this $\mathrm{Cq}$ in duplicates were considered positive. Samples with only one positive parallel were rerun and considered positive only with positive duplicates. The template volume was $2.0 \mu \mathrm{l}$ RNA in a total reaction volume of $20 \mu \mathrm{l}$, and the RT-qPCR kit used was TaqMan ${ }^{\circledR}$ Fast Virus 1-Step Master Mix (Applied Biosystems ${ }^{\circledR}$ ). The thermal programme comprised reverse transcription for $5 \mathrm{~min}$ at $50^{\circ} \mathrm{C}$ and enzyme activation for $2 \mathrm{~min}$ at $95^{\circ} \mathrm{C}$, followed by 45 cycles of $15 \mathrm{~s}$ at $94^{\circ} \mathrm{C}$ and $40 \mathrm{~s}$ at $60^{\circ} \mathrm{C}$. GraphPad Prism 4.03 (GraphPad Software) was used to plot the data.

\subsection{Check of RNA purity}

All tank water concentrates and tissue samples were evaluated for inhibitors that could impact the RT-qPCR and target quantification. RNA was, therefore, analyzed undiluted (1:1) and diluted (1:4) in duplicates, by RT-qPCR. Potential inhibition was detected when the Cq difference between the 1:1 and 1:4 samples was found to be less than $2 \mathrm{Cq}$. For these samples, the 1:4 dilution was used to estimate virus quantities.

\subsection{Quantification of SAV3}

A sample of purified SAV3 RNA (inter plate calibrator) was quantified by RT-ddPCR. The RT-ddPCR analysis was performed as described by Weli et al. (2021), by using the One-step RT-ddPCR Advanced Kit for Probe (Bio-Rad Laboratories), and the primers and probe used for the RT-qPCR assay, with the final concentrations of 900 and $250 \mathrm{nM}$, respectively.

A 2-fold serial dilution (1:1 to $\left.1: 2^{12}\right)$ was run by RTqPCR as a standard curve. The amplification efficiency $(E=94 \%)$, correlation coefficient $\left(\mathrm{r}^{2}=0.995\right)$ and slope of the linear regression line were all evaluated in accordance with Minimum Information for Publication of Quantitative Real-Time PCR Experiments (MIQE) guidelines (Taylor et al. 2010).

Quantification of SAV3 particles was performed based on the following formula: $N_{1}=N_{2} \times(1+E)^{\left(\mathrm{Cq}_{2}-\mathrm{Cq}_{1}\right)}$ (Christensen et al. 2017), where $N_{1}$ and $N_{2}$ represent the SAV3 copy number in the unknown sample and the calibrator, respectively and $\mathrm{Cq}_{1}$ and $\mathrm{Cq}_{2}$ represent the $\mathrm{SAV} 3$ detection in Cq values in the unknown sample and the calibrator, respectively. In order to estimate the number of viral particles in $1 \mathrm{l}$ of tank water concentrated with the first $\mathrm{CM}\left(\mathrm{CM}_{\mathrm{A}}\right)$, copy numbers were multiplied with $25 \times 2.4 \times 1 / R$ where $R$ (recovery) is approximately $25 \%$, as calculated according to Weli et al. (2021). The data were $\log _{10}$ transformed and plotted in GraphPad Prism 4.03 (GraphPad Software).

\subsection{Limit of detection and limit of quantification of SAV3}

The limit of quantification (LOQ) and limit of detection (LOD) values for the RT-qPCR were calculated using the following formulas: $\mathrm{LOQ}=10 \sigma / S$ and $\mathrm{LOD}=3.3 \sigma / S$, where $\sigma$ is the standard deviation of $y$-intercepts from 2 SAV3 standard curves and $S$ is the slope of the curve, according to the ICH Q2 (R1) guidelines (EMEA 1995). LOD and LOQ for SAV3 in 11 of tank water, using the $\mathrm{CM}_{\mathrm{A}}$ method, was estimated as described in Section 2.13.

Table 2. The Q_nsP1 assay was used for the detection of salmonid alphavirus subtype 3 (SAV3) in tissue samples and tank water concentrates, from the cohabitant challenge trial with post-smolt Atlantic salmon

\begin{tabular}{|llcccc|}
\hline Oligonucleotide & Sequence & Position & $\begin{array}{c}\text { Amplicon } \\
\text { length (bp) }\end{array}$ & $\begin{array}{c}\text { Reference } \\
\text { strain }\end{array}$ & Reference \\
\hline Q_nsP1 F primer & 5'-CCG GCC CTG AAC CAG TT-3' & $17-33$ & 107 & AY604235 Hodneland \& \\
R primer & 5'-GTA GCC AAG TGG GAG AAA GCT-3' & $54-69$ & & Endresen (2006) \\
Probe & FAM-5'-CTG GCC ACC ACT TCG A-3'-MGB & $103-123$ & & \\
\hline
\end{tabular}




\subsection{Statistical comparisons of $\mathrm{Cq}$ values}

In order to determine whether there was a statistically significant difference in performance between the $5 \mathrm{CMs}$, pairwise comparisons of the CMs were performed in one analysis (Model 1), and between the 2 membrane filters and the 4 buffer solutions with another (Model 2). Post hoc Tukey's HSD tests were used to achieve this goal. The performance was measured as Cq values from the RT-qPCR. Cq values were log transformed prior to the regressions to approximate normality. $\mathrm{Cq}$ values above 40 (i.e. no detection of SAV3 RNA) may constitute a problem for the assumption of normality, and were therefore removed. The virus was only detected in 2 observations in $\mathrm{T}_{\mathrm{L}}$ using $\mathrm{CM}_{\mathrm{E}}$ and was therefore clearly not suited to extract SAV3 RNA in this case, hence it was removed from the data set. Non-linear temporal autocorrelation was handled by modelling sampling time points (i.e. DPC) as a third-degree polynomial, since common approaches like a first-order autoregression (AR1) and autoregressive moving-average (ARMA) are not warranted for sampling designs with uneven sampling intervals. The inclusion of DPC will handle the development of the disease over time, as well as the removal of fish for tissue analysis. A forward model selection procedure was used to evaluate the inclusion of explanatory variables, using Akaike's information criterion (AIC) as an optimization criterion, and interactions were evaluated after the fixed effects were included. The best and the next best models were compared using an ANOVA table function in R. Explanatory variables, tried in the model selection for Model 1, were DPC (as a thirddegree polynomial), viral dose and CM. Explanatory variables tried in model selection for Model 2 were DPC (as a third-degree polynomial), viral dose, filter and buffer. The model was validated using a cross validation procedure: the data set was randomly split into training data ( $80 \%$ of the data set) and validation data $(20 \%)$. The model was refitted on the training data and used to predict the Cq values in the validation data set; predicted and observed validation data was stored. This procedure was repeated 10000 times. Predictive $\mathrm{R}^{2}$ values were calculated as the squared Pearson correlation coefficient between observed and predicted Cq values, and were used as a measure of how well the model is able to predict observations removed from the data set, in order to evaluate model overfitting in the linear models.

Associations between log-transformed $\mathrm{Cq}$ values in tank water concentrates and tissue (heart or midkidney) in both viral dose tanks $\left(\mathrm{T}_{\mathrm{L}}\right.$ and $\mathrm{T}_{\mathrm{H}}$ ) were estimated using a mixed effect linear model approach (Model 3) and backwards model selection, using AIC as an optimization criterion. The best and the second best models were compared using an ANOVA table function in R. Temporal autocorrelation and repeated measures ( 3 fish analyzed from each tank at each sampling time point) were handled by including DPC as a random intercept term, and viral dose tanks $\left(T_{L}\right.$ and $\left.T_{H}\right)$ as a fixed effect term. As a single water sample was analyzed by each CM at each sampling time point, sampling repeatability was deducted from the variability in the statistical model. This was done by simulating 1000 data sets from the model (using the 'simulate()-' function in R), and investigating the distribution of the simulated samplings.

All analyses were performed using the R statistical software (version 3.6.2), and multiple comparisons (Tukey's HSD test) based on the linear model were fitted using the 'multcomp' package (Hothorn et al. 2008). Mixed effect models were fitted using the 'lme4' package (Bates et al. 2015).

\section{RESULTS}

\subsection{Clinical signs}

Clinical signs associated with PD included an overall reduced appetite (i.e. failure to thrive), lethargy and abnormal swimming behavior and findings of faecal casts and mucus in the tank water. These signs were observed for the first time at 12 DPC in the high viral dose tank $\left(\mathrm{T}_{\mathrm{H}}\right)$ and at $16 \mathrm{DPC}$ in $\mathrm{T}_{\mathrm{L}}$ (Fig. 1).

\subsection{Mortality}

One dead cohabitant fish was observed in $\mathrm{T}_{\mathrm{L}}$, at 20 DPC, whereas no cohabitant fish died in $\mathrm{T}_{\mathrm{H}}$ until the last day of the challenge (1 fish died at $37 \mathrm{DPC}$; Fig. 1). In $T_{C}$, no fish died during the challenge period.

\subsection{Gross pathology}

Characteristic gross pathological changes associated with PD in cohabitant fish, including yellow mucoid gut content, empty intestines, ascites and petechial haemorrhages in the fat surrounding the pyloric caeca, were observed for the first time at 16 $\mathrm{DPC}$ in $\mathrm{T}_{\mathrm{H}}$ and at $20 \mathrm{DPC}$ in $\mathrm{T}_{\mathrm{L}}$, and thereafter 


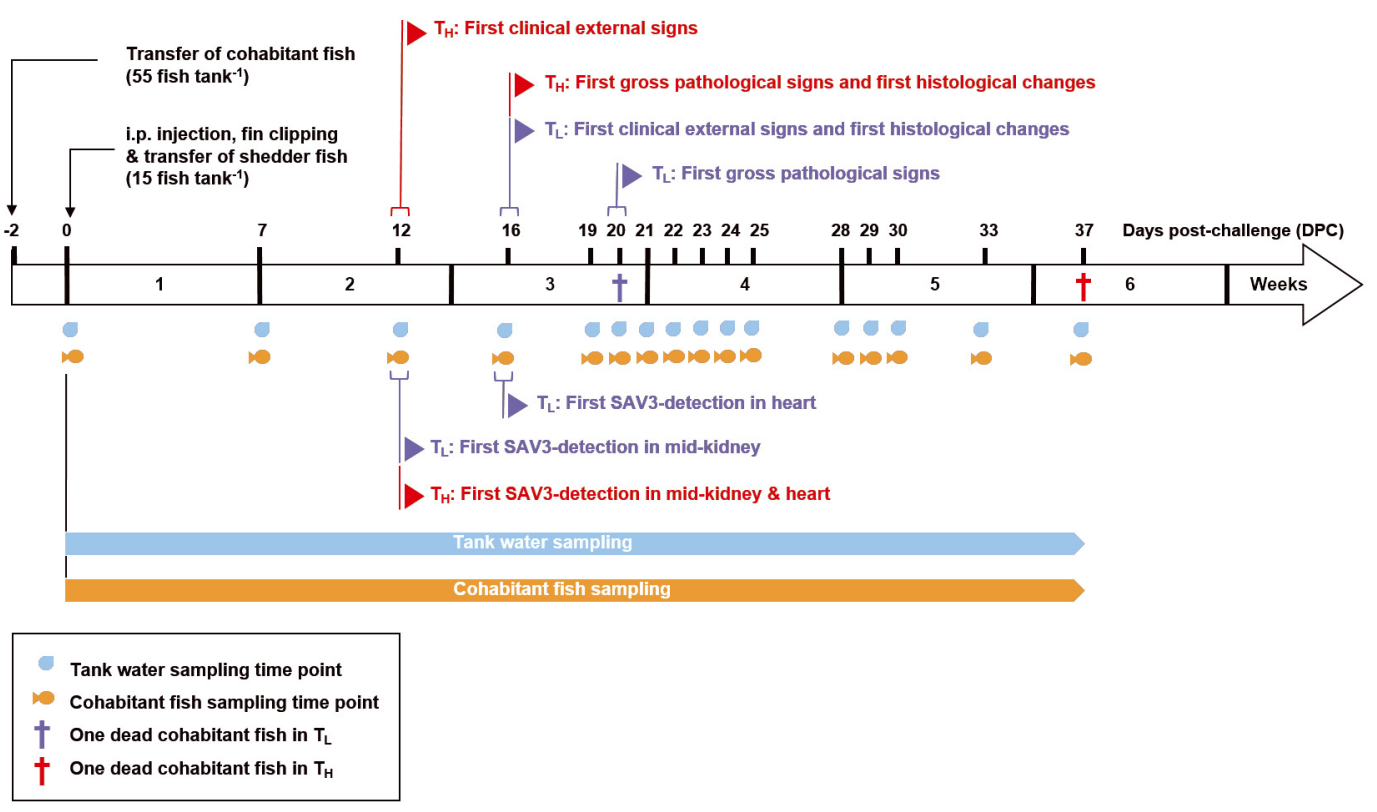

Fig. 1. Timeline for the salmonid alphavirus subtype 3 (SAV3) cohabitant challenge trial with post-smolt Atlantic salmon showing the 16 sampling time points, given as days post-challenge, for tank water and cohabitant fish. At Day 0, shedder fish were administered with a $0.2 \mathrm{ml}$ SAV3 inoculum by intraperitoneal (i.p.) injection and subsequently fin clipped prior to their distribution between the 3 different tanks: the low viral dose tank $\left(\mathrm{T}_{\mathrm{L}}: 2 \times 10^{2} 50 \%\right.$ tissue culture infective dose [TCID f $_{50}$ fish $\left.{ }^{-1}\right)$, the high viral dose tank $\left(\mathrm{T}_{\mathrm{H}}: 2 \times 10^{4} \mathrm{TCID}_{50}\right.$ fish $\left.^{-1}\right)$ and the negative control tank $\left(\mathrm{T}_{\mathrm{C}}\right.$ : virus-free L-15 [Leibovitz] medium)

observed at every sampling time point in almost all sampled fish in both $\mathrm{T}_{\mathrm{L}}$ and $\mathrm{T}_{\mathrm{H}}$. Additionally, cohabitant fish collected from $T_{L}$ had a more severe gross pathology associated with PD in the beginning of the challenge period compared to fish collected from $\mathrm{T}_{\mathrm{H}}$. For comparison, cohabitant fish from $\mathrm{T}_{\mathrm{C}}$ were also evaluated and had normal autopsy findings throughout the challenge.

\subsection{Histopathology}

Tissue samples from the cohabitant fish collected from $T_{L}$ and $T_{H}$ started presenting typical histopathological signs associated with SAV infection at 16 DPC, including necrosis and severe loss of exocrine pancreatic tissue and focal myocardial degeneration, evaluated by haematoxylin and eosin (H\&E) staining (except for the cardiac tissue sections from 3 cohabitants collected from $T_{L}$ at 16 DPC). Different levels of histopathological changes typical of SAV infection were found at all later sampling time points. For comparison, cohabitant fish collected from $\mathrm{T}_{\mathrm{C}}$ were evaluated at all sampling time points and presented intact and normal pancreatic and cardiac muscle tissues. The pancreatic tissue sections from the cohabitant fish sampled from $T_{L}$ and $T_{H}$ between 16, 29 and at $37 \mathrm{DPC}$ (one cohabitant fish from $\mathrm{T}_{\mathrm{L}}$ ) were positive by immunohistochemistry (IHC) staining for SAV, indicating acute SAV infection on these days.

\subsection{Detection of SAV3 in tissue samples}

A total of 94 tissue samples (2 were lost) from cohabitant fish from each of $\mathrm{T}_{\mathrm{L}}$ and $\mathrm{T}_{\mathrm{H}}$, and 32 from $\mathrm{T}_{\mathrm{C}}$ were analyzed by RT-qPCR. A majority were found to contain inhibition. Inter-individual variability was observed in the concentration of SAV3 RNA copy numbers detected in the tissue samples (midkidney and heart), in both $\mathrm{T}_{\mathrm{L}}$ and $\mathrm{T}_{\mathrm{H}}$. SAV3 was first detected in $\mathrm{T}_{\mathrm{H}}$ at $12 \mathrm{DPC}$ for both mid-kidney $(\mathrm{Cq}$ 27.9) and heart (Cq 27.0) (Fig. 2B), and in $\mathrm{T}_{\mathrm{L}}$ at 16 DPC for both mid-kidney (Cq 19.0) and heart (Cq 21.1) (Fig. 2A). Peak levels of SAV3 detection in the mid-kidney were seen at $19 \mathrm{DPC}$ in $\mathrm{T}_{\mathrm{L}}(\mathrm{Cq} 14.7)$ and at $16 \mathrm{DPC}$ in $\mathrm{T}_{\mathrm{H}}$ (Cq 19.9) (Fig. 2A,B). Peak levels of SAV3 detection in the heart were seen at 23 DPC in $\mathrm{T}_{\mathrm{L}}\left(\mathrm{Cq}\right.$ 15.0) and at $21 \mathrm{DPC}$ in $\mathrm{T}_{\mathrm{H}}$ (Cq 14.9) (Fig. 2A,B). On the last sampling time point (37 DPC), the highest SAV3 concentration was detected in the heart in $\mathrm{T}_{\mathrm{L}}$ (Cq 17.7), followed by the mid-kidney in $\mathrm{T}_{\mathrm{L}}$ (Cq 23.0), the heart in $\mathrm{T}_{\mathrm{H}}(\mathrm{Cq}$ 23.1) and the midkidney in $\mathrm{T}_{\mathrm{H}}$ (Cq 28.3). SAV3 was detected in all tissue samples from the onset until (and including) the last day of challenge (37 DPC) in both $\mathrm{T}_{\mathrm{L}}$ and $\mathrm{T}_{\mathrm{H}}$. 


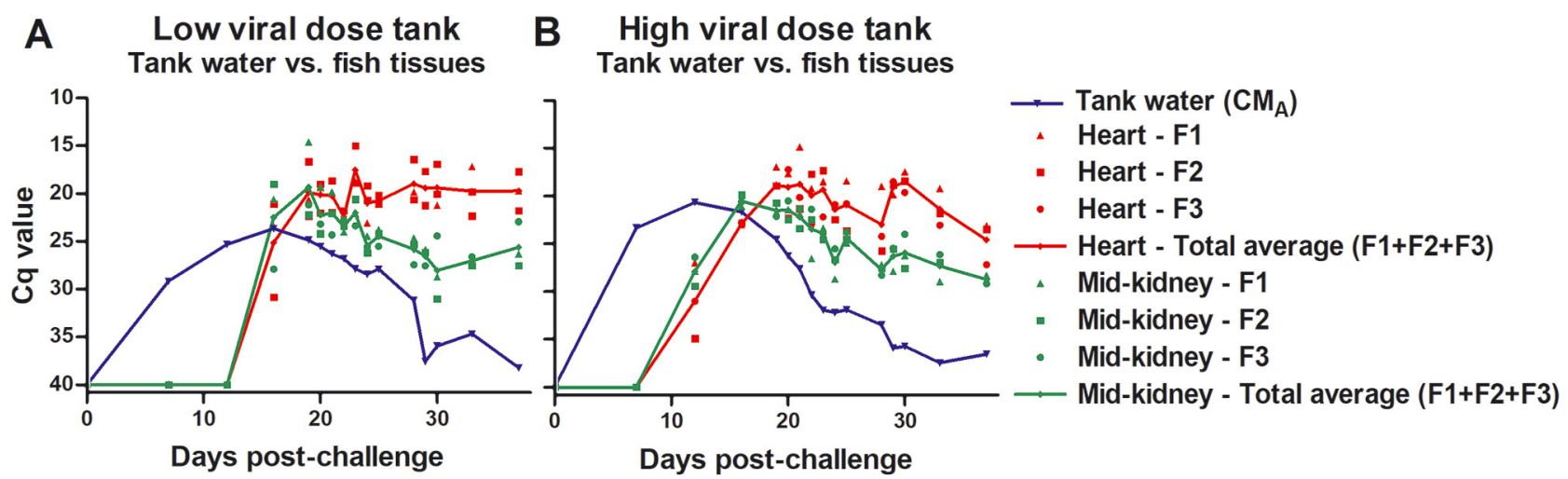

Fig. 2. Comparison between detection of salmonid alphavirus subtype 3 (SAV3) in 11 tank water concentrated with method A $\left(\mathrm{CM}_{\mathrm{A}}\right)$ and in tissue samples (mid-kidney and heart) from cohabitant fish sampled during the SAV3 cohabitant challenge. The samples were analysed by RT-qPCR. The SAV3 concentration is presented as the average quantification cycle (Cq) values per days post-challenge in the $(A)$ low viral dose tank $\left(T_{L}\right)$ and $(B)$ high viral dose tank $\left(T_{H}\right)$. Tank water samples were collected simultaneously with the collection of the 3 cohabitant fish $\operatorname{tank}^{-1}$ (F1: fish 1; F2: fish 2; F3: fish 3) at 16 sampling time points, from both $\mathrm{T}_{\mathrm{L}}$ and $\mathrm{T}_{\mathrm{H}}$

Tissue samples collected from $\mathrm{T}_{\mathrm{C}}$ were found to be negative by RT-qPCR.

\subsection{Detection of SAV3 in tank water samples}

Eighty 11 water samples were collected from each of the 3 tanks $\left(\mathrm{T}_{\mathrm{L}}, \mathrm{T}_{\mathrm{H}}\right.$ and $\left.\mathrm{T}_{\mathrm{C}}\right)$, resulting in a total of 240 samples that were analysed by RT-qPCR, and the majority of these samples were found to contain inhibitors. The first detection of SAV3 was made on the second sampling time point ( 7 DPC) in both $T_{L}$ and $\mathrm{T}_{\mathrm{H}}$, with all CMs except $\mathrm{CM}_{\mathrm{E}}$.

\subsection{Comparison of the $5 \mathrm{CMs}\left(\mathrm{CM}_{\mathrm{A}-\mathrm{E}}\right)$}

Compared with the other $4 \mathrm{CMs}$, Fig. 3 revealed a general tendency for $\mathrm{CM}_{\mathrm{A}}$, the combination of electronegative filter with buffer 1, to be best in recovering SAV3 from 7 DPC until the end of challenge. This tendency can be observed in both $T_{L}$ and $T_{H}$, but with a stronger tendency in the latter (Fig. 3A,B). Additionally, the period of virus detection was narrower and had a higher detection peak in the $\mathrm{T}_{\mathrm{H}}$ compared to $\mathrm{T}_{\mathrm{L}}$ (Fig. 3C,D). When using $\mathrm{CM}_{\mathrm{A}}$, the first SAV3 detection in tank water was made at $7 \mathrm{DPC}$ in both $\mathrm{T}_{\mathrm{L}}$ and $\mathrm{T}_{\mathrm{H}}$; the peak of viral shedding occurred earlier in $\mathrm{T}_{\mathrm{H}}(12 \mathrm{DPC})$, with $3.42 \times 10^{6}$ SAV3 RNA copies $1^{-1}\left(6.53 \log _{10}\right.$ copies $\left.1^{-1}\right)$, than in $\mathrm{T}_{\mathrm{L}}(16 \mathrm{DPC})$, with $4.7 \times 10^{5}$ SAV3 RNA copies $\mathrm{l}^{-1}$ $\left(5.67 \log _{10}\right.$ copies $1^{-1}$ ) (Fig. 3C,D). Water samples collected from $\mathrm{T}_{\mathrm{C}}$ were negative, except for one sample collected at 19 DPC (Cq 34.6), when using $\mathrm{CM}_{\mathrm{D}}$. The simulated samplings from the statistical model showed that the Cq values varied between 19.7 and 45.0 for $\mathrm{CM}_{\mathrm{A}}$ in both tanks over the entire course of the challenge. More than $99 \%$ of these simulated samplings returned $\mathrm{Cq}$ values below 40, indicating that we would have detected SAV in more than $99 \%$ of the samples at any time point after 7 DPC.

The best fitted model for CM (Model 1) included a CM, DPC as a third-degree polynomial (allowing non-linear time trends in the development of the infection during the challenge period) and viral dose (ANOVA model comparison: $p<0.001$ ). The model also included interactions between $\mathrm{CM}$ and viral dose, and between viral dose and DPC, allowing a slower development of the infection and a lower peak in $\mathrm{T}_{\mathrm{L}}$. The model became quite complex, and overfitting was a serious concern. The predicted $\mathrm{R}^{2}$ from cross validation (0.78) was close to the multiple $\mathrm{R}^{2}(0.84)$, proving that the model can predict observations that were excluded from the training data with good precision. Pairwise comparisons revealed that $\mathrm{CM}_{\mathrm{A}}$ returned significantly lower $\mathrm{Cq}$ values than all the other CMs when SAV3 was detected in $T_{H}$ (Table 3; $\mathrm{CM}_{\mathrm{A}}$ : p-values between 0.004 and <0.001), but $\mathrm{CM}_{\mathrm{A}}$ was not different from $\mathrm{CM}_{\mathrm{B}}$ in $\mathrm{T}_{\mathrm{L}}(\mathrm{p}=$ 0.988).

The best fitted model for filter and buffer (Model 2) included filter, buffer, DPC (as a third-degree polynomial) and viral dose, in addition to interactions between viral dose and DPC, and between viral dose and filter (ANOVA model comparison: $p<0.001$ ). The predicted $R^{2}(0.78)$ was close to the multiple $R^{2}$ (0.84), proving that the model can predict observations that were excluded from the training data with 

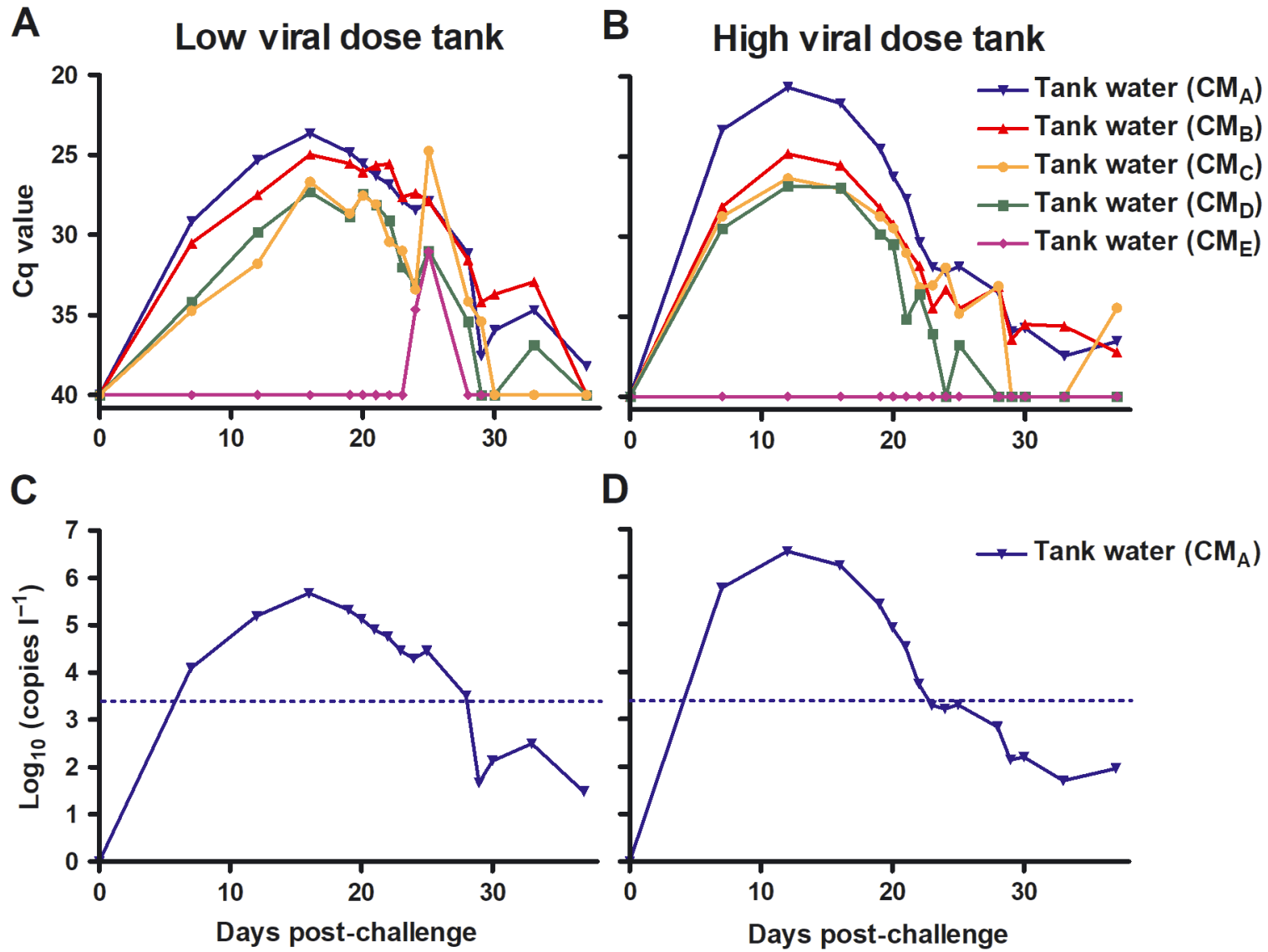

Fig. 3. Detection of salmonid alphavirus subtype 3 (SAV3) from tank water sampled at 16 time points, given as days post-challenge (DPC) throughout the SAV3 cohabitant challenge trial with post-smolt Atlantic salmon. The samples were analyzed by RT-qPCR. Five methods $\left(\mathrm{CM}_{\mathrm{A}-\mathrm{E}}\right)$ were used to concentrate SAV3 from $1 \mathrm{l}$ of tank water in the low viral dose tank ( $\left.\mathrm{T}_{\mathrm{L}}\right)$ and high viral dose tank $\left(\mathrm{T}_{\mathrm{H}}\right)$. Both $(\mathrm{A}, \mathrm{B})$ quantification cycle $(\mathrm{Cq})$ values per DPC and $(\mathrm{C}, \mathrm{D}) \mathrm{SAV} 3 \mathrm{copies}^{-1}$ of tank water DPC ${ }^{-1}$ are presented. Dotted horizontal line: limit of quantification when using $\mathrm{CM}_{\mathrm{A}}$

good precision. Pairwise comparisons revealed that buffer 1 performed significantly better than buffers 2 and 3 ( $\mathrm{p}<0.001$ for both comparisons), and the electronegative filter performed significantly better than electropositive for $\mathrm{T}_{H}(\mathrm{p}=0.002)$, but not for $\mathrm{T}_{\mathrm{L}}(\mathrm{p}=$ 0.91) (Table 3).

\subsection{LOD and LOQ of SAV3 in 1 l of tank water}

The LOD and LOQ when using CMA were 902 and 2736 SAV3 RNA copies $1^{-1}$, respectively.

\subsection{Detection of SAV3 in tank water concentrates vs. tissue samples}

Associations between virus recovery in tissue samples and tank water concentrates were explored using a linear mixed effect model (Model 3). The model was fitted using a backwards model selection (AIC). The full model (before model selection) explained the tank water concentrates' Cq values for SAV3 detection as the effect of DPC (as a random intercept term), viral dose (as a factor variable), tissue samples' Cq values for SAV3 detection and the interaction between the $\mathrm{Cq}$ values for tissue samples and dose. Any removal of explanatory terms gave a poorer fit, and the full model was therefore kept (confirmed by the ANOVA model comparison, $\mathrm{p}=$ 0.02). The model output is presented in Table 4. A significant positive association was established between the $\mathrm{Cq}$ values for mid-kidney samples and tank water concentrates $(p=0.0084)$ in both $T_{L}$ and $\mathrm{T}_{\mathrm{H}}$. The effect of viral dose and the interaction were significant $(\mathrm{p}<0.038$ and $\mathrm{p}=0.024$, respectively). No significant effect was found with a similar approach for heart tissue samples $(p=0.26)$. 
Table 3. Post hoc Tukey HSD tests, based on the linear models (Models 1 and 2 ), exploring how the quantification cycle (Cq) values for the detection of salmonid alphavirus subtype 3 (SAV3) could be explained by the concentration method (CM), the 2 membrane filters (electropositive or electronegative) and the 3 buffer solutions (buffers 1,2 and 3) used for the concentration of SAV3 from 11 tank water. The columns indicate the null hypotheses, the mean differences and the p-values. Note that there was an interaction between CM and viral dose in both models. Tukey comparisons (contrasts) in these cases are shown for detected SAV3

\begin{tabular}{|c|c|c|}
\hline Tukey null hypotheses & $\begin{array}{l}\text { Mean difference } \\
\text { of } \log (\mathrm{Cq})\end{array}$ & $\mathrm{p}$ \\
\hline \multicolumn{3}{|l|}{$\mathrm{CM}$ in high viral dose tank (model 1$)^{\mathrm{a}}$} \\
\hline $\mathrm{CM}_{\mathrm{B}}-\mathrm{CM}_{\mathrm{A}}=0$ & 0.073 & 0.004 \\
\hline $\mathrm{CM}_{\mathrm{D}}-\mathrm{CM}_{\mathrm{A}}=0$ & 0.16 & $<0.001$ \\
\hline $\mathrm{CM}_{\mathrm{C}}-\mathrm{CM}_{\mathrm{A}}=0$ & 0.092 & $<0.001$ \\
\hline $\mathrm{CM}_{\mathrm{D}}-\mathrm{CM}_{\mathrm{B}}=0$ & 0.088 & 0.003 \\
\hline $\mathrm{CM}_{\mathrm{C}}-\mathrm{CM}_{\mathrm{B}}=0$ & 0.019 & 0.820 \\
\hline $\mathrm{CM}_{\mathrm{C}}-\mathrm{CM}_{\mathrm{D}}=0$ & -0.069 & 0.040 \\
\hline \multicolumn{3}{|l|}{$\mathrm{CM}$ in low viral dose tank (model 1$)^{\mathrm{a}}$} \\
\hline $\mathrm{CM}_{\mathrm{B}}-\mathrm{CM}_{\mathrm{A}}=0$ & -0.0069 & 0.988 \\
\hline $\mathrm{CM}_{\mathrm{D}}-\mathrm{CM}_{\mathrm{A}}=0$ & 0.098 & $<0.001$ \\
\hline $\mathrm{CM}_{\mathrm{C}}-\mathrm{CM}_{\mathrm{A}}=0$ & 0.087 & 0.001 \\
\hline $\mathrm{CM}_{\mathrm{D}}-\mathrm{CM}_{\mathrm{B}}=0$ & 0.10 & $<0.001$ \\
\hline $\mathrm{CM}_{\mathrm{C}}-\mathrm{CM}_{\mathrm{B}}=0$ & 0.094 & $<0.001$ \\
\hline $\mathrm{CM}_{\mathrm{C}}-\mathrm{CM}_{\mathrm{D}}=0$ & -0.011 & 0.968 \\
\hline \multicolumn{3}{|l|}{ Filter and buffer (model 2) ${ }^{\mathrm{a}}$} \\
\hline Electropositive - Electronegative, high viral dose & -0.064 & 0.002 \\
\hline Electropositive - Electronegative, low viral dose & 0.0023 & $<0.909$ \\
\hline Buffer $1-$ Buffer $3=0$ & -0.13 & $<0.001$ \\
\hline Buffer $2-$ Buffer $3=0$ & -0.036 & 0.101 \\
\hline Buffer $2-$ Buffer $1=0$ & 0.089 & $<0.001$ \\
\hline${ }^{\text {aSee Table } 1}$ & & \\
\hline
\end{tabular}

tropositive filter used herein, although the filters were indistinguishable in samples from $\mathrm{T}_{\mathrm{L}}$. This conclusion is also consistent with the above-mentioned in vitro study, in which we concluded that the same combination of the electronegative filter and Nucli SENS ${ }^{\circledR}$ easyMAG ${ }^{\circledR}$ Lysis Buffer provided the best SAV3 recovery from seawater (Weli et al. 2021). The method combining the electropositive filter and NucliSENS ${ }^{\circledR}$ easyMAG ${ }^{\circledR}$ Lysis Buffer $\left(\mathrm{CM}_{\mathrm{B}}\right)$ also resulted in higher SAV3 recovery compared to the other $3 \mathrm{CMs}\left(\mathrm{CMc}_{\mathrm{C}}, \mathrm{CM}_{\mathrm{D}}\right.$ and $\mathrm{CM}_{\mathrm{E}}$ ), thus strengthening the importance of the NucliSENS ${ }^{\circledR}$ easyMAG ${ }^{\circledR}$ Lysis Buffer, as stated by our previous in vitro study (Weli et al. 2021).

Horizontal transmission of SAV via water has been confirmed by other experimental challenge studies, in which SAV was detected directly from seawater using filtration (Andersen et al. 2010, Jarungsriapisit et al. 2016a,b, 2020). In these studies, an electropositive 1 MDS filter was used for filtration of 11 seawater, followed by rinsing of the filter using lysis buffer (Andersen et al. 2010, Jarungsriapisit et al. $2016 b)$ or L-15 supplemented with

\section{DISCUSSION}

In the present study, we present a successful CM for detection of SAV3 in seawater. We have previously demonstrated the potential of this method for recovery of SAV3 spiked into natural seawater (Weli et al. 2021). However, in order to optimise the method for the field, $5 \mathrm{CMs}\left(\mathrm{CM}_{\mathrm{A}-\mathrm{E}}\right)$, based on 2 different membrane filters and 4 different buffer solutions, were evaluated for their ability to recover SAV3 from tank water collected during a cohabitant challenge trial, when post-smolt Atlantic salmon had developed clinical infection with SAV.

The method combining the electronegative membrane filter and NucliSENS ${ }^{\circledR}$ easyMAG ${ }^{\circledR}$ Lysis Buffer $\left(\mathrm{CM}_{\mathrm{A}}\right)$ had the highest SAV3 recovery and the most consistent SAV3 detection in tank water samples from $T_{H}$ throughout the challenge, but virus recovery using $\mathrm{CM}_{\mathrm{A}}$ or $\mathrm{CM}_{\mathrm{B}}$ was indistinguishable in samples from $T_{L}$. This buffer solution and the electronegative membrane filter performed significantly better compared to the other buffer solutions and the elec-
$10 \%$ FBS (Jarungsriapisit et al. 2016a, 2020). In other words, none of these studies used the filter/buffer combination $\left(\mathrm{CM}_{\mathrm{A}}\right)$ that proved most successful in the present study. However, in this context it is important to highlight that the subsequent processing of the filtrate (i.e. RNA extraction) and the PCR assay used can also impact on the method's success in detecting SAV3 from seawater.

Although the cohabitation challenge model, as used in this study, does not represent the natural route of infection (since the initiation of infection was done via i.p. injection of shedder fish), it does simulate spread of the virus and a natural exposure route to the cohabitant fish.

McLoughlin \& Graham (2007) suggested that the incubation period for SAV may be 7-10 d at seawater temperatures of $12-15^{\circ} \mathrm{C}$. In the present study, the tank water temperature was approximately $12^{\circ} \mathrm{C}$, and SAV3 was first detected in the tank water at 7 DPC, compared to in cohabitant fish tissue at $16 \mathrm{DPC}$ in $\mathrm{T}_{\mathrm{L}}$ and at $12 \mathrm{DPC}$ in $\mathrm{T}_{\mathrm{H}}$. However, the early detections of SAV3 in the tank water may have been 
Table 4. The most parsimonious model explaining the association between quantification cycle $(\mathrm{Cq})$ values for detection of salmonid alphavirus subtype 3 (SAV3) in the mid-kidney samples and in the tank water concentrates. Only fixed effects from the model are shown. Note that Cq values are log transformed in the response; ' $x$ ' means interaction. Baseline for the model output is high dose. This means that the intercept and $\log$ (mid-kidney $\times$ Cq-values) from the table are parameters in a linear function between log(tank water $\mathrm{Cq}$ values) and $\log$ (mid-kidney Cq values) in samples from the high viral dose tank. In this case the model takes the form ' $a+b x^{\prime}$, where ' $a$ ' is the intercept estimate and ' $b$ ' (the slope) is the log(mid-kidney Cq values) estimate. The estimate for low viral dose is presented as the deviation from the intercept for high viral dose, and the ' $\log$ (mid-kidney Cq values) $\times$ low viral dose' estimate is presented as the deviation from the slope for high viral dose. The ' $a$ ' in the linear function for low viral dose becomes the intercept + low viral dose estimates, and ' $b$ ' is the $\log$ (mid-kidney Cq values) $+\log$ (mid-kidney Cq values) $\times$ low viral dose estimates

\begin{tabular}{|lclc|}
\hline Variable & Estimate & SE & $\mathrm{p}$ \\
\hline Intercept & 2.7 & 0.27 & $<0.001$ \\
log(mid-kidney Cq values) & 0.22 & 0.081 & $<0.008$ \\
Low viral dose & -0.51 & 0.24 & $<0.038$ \\
log(mid-kidney Cq values) $\times$ low viral dose & -0.17 & 0.076 & 0.024 \\
\hline
\end{tabular}

virus excreted from the shedder fish that remained in the tanks throughout the challenge.

In contrast to the in vitro study (Weli et al. 2021), the present study involved filtration of tank water that contained a high amount of organic matter (e.g. faecal casts, mucus and pellets). Furthermore, the tank water samples were collected approximately $15 \mathrm{~cm}$ below the water surface of the tanks, and a previous study (Stene et al. 2016) has identified accumulated levels of SAV in surface lipids due to fat droplets leaking from dead and SAV-infected fish. Hence, the detected SAV3 from the tank water in the present study could have been influenced by the inevitable inclusion of the fat droplets and/or organic matter (e.g. faecal casts and mucus) that have been found positive for SAV3 RNA, as shown by previous research (Graham et al. 2011).

In the present study, SAV3-infection in cohabitant fish was confirmed by gross pathology, histopathology and clinical signs associated with PD (Nelson et al. 1995, McLoughlin et al. 1996, 2002, Taksdal et al. 2015, Jansen et al. 2017), as well as by RT-qPCR analysis.

Heart and mid-kidney, which are the recommended organs for SAV detection according to the World Organisation for Animal Health (OIE) and are used in the Norwegian surveillance program (Lovdata 2017), were sampled from cohabitant fish in the present study. A significant positive correlation was found throughout the challenge between the levels of SAV3 in the tank water samples and in the midkidney samples collected from the cohabitant fish in both $\mathrm{T}_{\mathrm{L}}$ and $\mathrm{T}_{\mathrm{H}}$. This observation supports that the cohabitant fish provided a significant contribution to virus levels in the tank water throughout the challenge. No correlation was found between virus concentrations in the tank water samples and the heart samples, either in $\mathrm{T}_{\mathrm{L}}$ or in $\mathrm{T}_{\mathrm{H}}$. However, the virus concentrations were generally found to be higher in the heart samples compared to the mid-kidney.

Tank water samples were collected consistently from all 3 tanks before the collection of the cohabitant fish, ensuring that the fish would not be exposed to stress that might cause them to increase their shedding rate prior to the water sampling. The water flow rate in all 3 tanks was constantly high $\left(950 \mathrm{l} \mathrm{h}^{-1}\right)$, ensuring not only optimal oxygen levels for the fish, but also providing self-cleaning of the tanks throughout the challenge. Hence, it is highly suspected that the one water control which was found to be SAV3-positive when using $\mathrm{CM}_{\mathrm{D}}$ was due to cross-contamination during sampling or sample processing.

Monitoring for the presence of SAV3 in the tank water sampled during the challenge period was done by RT-qPCR, which enables high performance in detection of waterborne RNA viruses at low concentrations (Girones et al. 2010, Rački et al. 2014a,b). RTqPCR has been reported to be more sensitive to inhibitors than qPCR (Girones et al. 2010), which may cause lower quantification precision (i.e. larger coefficients of variation) (Rački et al. 2014a). Since the present study involved sampling of natural seawater, in which both salts and other RT-qPCR inhibitors are expected to have an influence on RNA-virus quantification, a check of inhibition was made for all tank water samples, and inhibition was indeed present in a majority of the samples (hence the 1:4 dilution was considered for these). Therefore there is an advantage of using RT-ddPCR on these samples, as this method is less sensitive to any effect of inhibitors (Rački et al. 2014a,b). The method is more expensive compared to RT-qPCR, but the samples could then be run on undiluted RNA only.

The SAV3 concentrations (based on Cq values) in tissue samples were higher overall compared to intank water samples. This is an expected finding because the fish (in contrast to the water) serve as a replication site for the virus. However, in this context, it is important to highlight that the detection method 
used for tissue is different than the method used for water, and therefore these methods are not comparable in terms of differences in the amount of detected virus.

In laboratory as well as in field studies, the sensitivity of the detection methods should be evaluated according to whether the method is able to detect the virus when there are SAV3-infected fish in the population. In order to compare the sensitivity of the water sampling method to a surveillance method based on sampling of fish under field conditions, the comparison will be between the LOD for the water sampling method on the one side, and the probability of sampling an infected fish on the other. For both methods, the sensitivity will obviously depend on the prevalence of SAV3-infected fish in the population. However, a water sample serves as a representation of the environment of a large number of fish, and if the water sampling method can detect the virus at a low prevalence of SAV in the fish population, it may increase the probability for early detection of SAV in a fish farm.

Based on these findings, the combination of an electronegative charged filter (MF-Millipore ${ }^{\mathrm{TM}} 0.45 \mu \mathrm{m}$ MCE membrane; Merck Millipore) and NucliSENS ${ }^{\circledR}$ easyMAG ${ }^{\circledR}$ Lysis Buffer (bioMérieux) is considered to have the best potential in serving as a more costefficient, straightforward, rapid, reliable, reproducible and animal-welfare friendly method for concentration and detection of SAV3 and potentially other SAV subtypes from seawater. This new method will be tested for surveillance of farmed salmonid populations as a part of a biosecurity plan for SAV under natural field conditions. The method might allow warning and earlier implementation of disease control measures on farms neighbouring farms with identified SAV, which would be of significance in Atlantic salmon health management.

Acknowledgements. This study was supported financially by the Research Council of Norway (NFR). We thank Linda Andersen and Steffen H. Blindheim at the Industrial and Aquatic Laboratory (ILAB, Bergen) for providing facilities and for their support during this challenge; Hilde Sindre for providing the SAV3 isolate; Estelle Grønneberg for her molecular expertise and support; Lars Austbø, Bjørn Spilsberg, Wenche Støldal Gulliksen and Torfinn Moldal at the department of Molecular Biology (NVI, Oslo); Ingebjørg Modahl at the department of Immunology and Virology (NVI, Oslo); Saima Nasrin Mohammad and David Strand at the department of Fish Health Research Group (NVI, Oslo); Karoline Sveinsson at the Department of Research and Aquatic Biosecurity (NVI, Oslo) for her histological expertise; Inger Böckerman; and colleagues at the Department of Pathology (NVI, Oslo) for cutting sections and staining.

\section{LITERATURE CITED}

Andersen L, Hodneland K, Nylund A (2010) No influence of oxygen levels on pathogenesis and virus shedding in salmonid alphavirus (SAV)-challenged Atlantic salmon (Salmo salar L.). Virol J 7:198

* Bates D, Mächler M, Bolker B, Walker S (2015) Fitting linear mixed-effects models using lme4. J Stat Softw 67:1-48

bioMérieux (2009) NucliSENS ${ }^{\text {TM }}$ easyMAG user manual. https://www.manualslib.com/manual/1377074/Biomeri eux-Nuclisens-Easymag.html

* Cashdollar JL, Wymer L (2013) Methods for primary concentration of viruses from water samples: a review and meta-analysis of recent studies. J Appl Microbiol 115: 1-11

Christensen E, Nilsen V, Håkonsen T, Heistad A, Gantzer C, Robertson LJ, Myrmel M (2017) Removal of model viruses, E. coli and Cryptosporidium oocysts from surface water by zirconium and chitosan coagulants. J Water Health 15:695-705

*Deperasińska I, Schulz P, Siwicki AK (2018) Salmonid alphavirus (SAV). J Vet Res 62:1-6

EMEA (European Medicines Agency) (1995) ICH Q2 (R1): validation of analytical procedures: text and methodology. Step 5. https://www.ema.europa.eu/en/documents/ scientific-guideline/ich-q-2-r1-validation-analytical-pro cedures-text-methodology-step-5_en.pdf

F Farrah SR, Gerba CP, Wallis C, Melnick JL (1976) Concentration of viruses from large volumes of tap water using pleated membrane filters. Appl Environ Microbiol 31: 221-226

Fringuelli E, Rowley HM, Wilson JC, Hunter R, Rodger $\mathrm{H}$, Graham DA (2008) Phylogenetic analyses and molecular epidemiology of European salmonid alphaviruses (SAV) based on partial E2 and nsP3 gene nucleotide sequences. J Fish Dis 31:811-823

*Girones R, Ferrús MA, Alonso JL, Rodriguez-Manzano J and others (2010) Molecular detection of pathogens in water-the pros and cons of molecular techniques. Water Res 44:4325-4339

Goyal SM, Gerba CP (1983) Viradel method for detection of rota virus from seawater. J Virol Methods 7:279-285

*Gaham DA, Frost P, McLaughlin K, Rowley HM, Gabestad I, Gordon A, McLoughlin MF (2011) A comparative study of marine salmonid alphavirus subtypes 1-6 using an experimental cohabitation challenge model. J Fish Dis 34:273-286

Graham DA, Brown A, Savage P, Frost P (2012) Detection of salmon pancreas disease virus in the faeces and mucus of Atlantic salmon, Salmo salar L., by real-time RT-PCR and cell culture following experimental challenge. J Fish Dis 35:949-951

*Hortaas MJ, Bang Jensen B, Taksdal T, Olsen AB, Lillehaug A, Trettenes E, Sindre H (2016) Genetic characterization of salmonid alphavirus in Norway. J Fish Dis 39:249-257

*Hodneland K, Endresen C (2006) Sensitive and specific detection of Salmonid alphavirus using real-time PCR (TaqMan ${ }^{\circledR}$ ). J Virol Methods 131:184-192

Hodneland K, Bratland A, Christie KE, Endresen C, Nylund A (2005) New subtype of salmonid alphavirus (SAV), Togaviridae, from Atlantic salmon Salmo salar and rainbow trout Oncorhynchus mykiss in Norway. Dis Aquat Org 66:113-120

*Hothorn T, Bretz F, Westfall P (2008) Simultaneous inference in general parametric models. Biom J 50:346-363 
Jansen MD, Bang Jensen B, Taksdal T, Sindre H, Lillehaug A (2015) Pankreassykdom hos laksefisk-en review med fokus på forebygging, kontroll og bekjempelse. Veterinærinstituttets rapportserie 5-2015. Veterinærinstituttet, Oslo

Jansen MD, Bang Jensen B, McLoughlin MF, Rodger HD and others (2017) The epidemiology of pancreas disease in salmonid aquaculture: a summary of the current state of knowledge. J Fish Dis 40:141-155

Jarungsriapisit J, Moore LJ, Mæhle S, Skår C and others (2016a) Relationship between viral dose and outcome of infection in Atlantic salmon, Salmo salar L., post-smolts bath-challenged with salmonid alphavirus subtype 3 . Vet Res 47:102

Jarungsriapisit J, Moore LJ, Taranger GL, Nilsen TO and others (2016b) Atlantic salmon (Salmo salar L.) postsmolts challenged two or nine weeks after seawatertransfer show differences in their susceptibility to salmonid alphavirus subtype 3 (SAV3). Virol J 13:66

Jarungsriapisit J, Nuñez-Ortiz N, Nordbø J, Moore LJ, Mæhle S, Patel S (2020) The effect of temperature on the survival of salmonid alphavirus analysed using in vitro and in vivo methods. Aquaculture 516:734647

Lovdata (2017) Forskrift om tiltak for å forebygge, begrense og bekjempe pankreassykdom (PD) hos akvakulturdyr. https://lovdata.no/forskrift/2017-08-29-1318 (accessed 11 September 2020)

McLoughlin MF, Graham DA (2007) Alphavirus infections in salmonids - a review. J Fish Dis 30:511-531

McLoughlin MF, Nelson RT, Rowley HM, Cox DI, Grant AN (1996) Experimental pancreas disease in Atlantic salmon Salmo salar post-smolts induced by salmon pancreas disease virus (SPDV). Dis Aquat Org 26:117-124

McLoughlin MF, Nelson RN, McCormick JI, Rowley HM, Bryson DB (2002) Clinical and histopathological features of naturally occurring pancreas disease in farmed Atlantic salmon, Salmo salar L. J Fish Dis 25:33-43

Munro A, Ellis A, McVicar A, McLay H, Needham E (1984) An exocrine pancreas disease of farmed Atlantic salmon in Scotland. Helgol Meeresunters 37:571-586

Nelson RT, McLoughlin MF, Rowley HM, Platten MA, McCormick JI (1995) Isolation of a toga-like virus from farmed Atlantic salmon Salmo salar with pancreas disease. Dis Aquat Org 22:25-32

Poppe T, Rimstad E, Hyllseth B (1989) Pancreas disease in Atlantic salmon (Salmo salar) postsmolts infected with infectious pancreatic necrosis virus (IPNV). Bull Eur Assoc Fish Pathol 9:83-85

Rački N, Dreo T, Gutierrez-Aguirre I, Blejec A, Ravnikar M (2014a) Reverse transcriptase droplet digital PCR shows high resilience to PCR inhibitors from plant, soil and water samples. Plant Methods 10:42

Rački N, Morisset D, Gutierrez-Aguirre I, Ravnikar M (2014b) One-step RT-droplet digital PCR: a break-

Editorial responsibility: Catherine Collins,

Jouy-en-Josas, France

Reviewed by: 2 anonymous referees through in the quantification of waterborne RNA viruses. Anal Bioanal Chem 406:661-667

Reed LJ, Muench H (1938) A simple method of estimating fifty per cent endpoints. Am J Epidemiol 27:493-497

Rusch JC, Hansen H, Strand DA, Markussen T, Hytterød S, Vrålstad T (2018) Catching the fish with the worm: a case study on eDNA detection of the monogenean parasite Gyrodactylus salaris and two of its hosts, Atlantic salmon (Salmo salar) and rainbow trout (Oncorhynchus mykiss). Parasit Vectors 11:333

* Rusch JC, Mojžišová M, Strand DA, Svobodová J, Vrålstad T, Petrusek A (2020) Simultaneous detection of native and invasive crayfish and Aphanomyces astaci from environmental DNA samples in a wide range of habitats in Central Europe. NeoBiota 58:1-32

* Sommerset I, Walde SC, Bang Jensen B, Bornø G, Haukaas A, Brun E (eds) (2020) Fiskehelserapporten 2019 Rapport 5a/2020. https://www.vetinst.no/rapporter-ogpublikasjoner/rapporter/2020/fiskehelserapporten-2019 (accessed 11 September 2020)

Stene A, Hellebø A, Viljugrein H, Solevåg SE, Devold M, Aspehaug V (2016) Liquid fat: A potential abiotic vector for horizontal transmission of salmonid alphavirus? J Fish Dis 39:531-537

Strand DA, Johnsen SI, Rusch JC, Agersnap S and others (2019) Monitoring a Norwegian freshwater crayfish tragedy: eDNA snapshots of invasion, infection and extinction. J Appl Ecol 56:1661-1673

Taksdal T, Bang Jensen B, Böckerman I, McLoughlin MF, Hjortaas MJ, Ramstad A, Sindre H (2015) Mortality and weight loss of Atlantic salmon, Salmon salar L., experimentally infected with salmonid alphavirus subtype 2 and subtype 3 isolates from Norway. J Fish Dis 38: 1047-1061

* Taylor S, Wakem M, Dijkman G, Alsarraj M, Nguyen M (2010) A practical approach to RT-qPCR-publishing data that conform to the MIQE guidelines. Methods 50: $\mathrm{S} 1-\mathrm{S} 5$

*Wallis C, Henderson M, Melnick JL (1972) Enterovirus concentration on cellulose membranes. Appl Microbiol 23: 476-480

Weli SC, Bernhardt LV, Qviller L, Myrmel M, Lillehaug A (2021) Development and evaluation of a method for concentration and detection of salmonid alphavirus from seawater. J Virol Methods 287:113990

*Weston J, Villoing S, Bremont M, Castric J and others (2002) Comparison of two aquatic alphaviruses, salmon pancreas disease virus and sleeping disease virus, by using genome sequence analysis, monoclonal reactivity, and cross-infection. J Virol 76:6155-6163

Xu C, Guo TC, Mutoloki S, Haugland Ø, Evensen Ø (2012) Gene expression studies of host response to salmonid alphavirus subtype 3 experimental infections in Atlantic salmon. Vet Res 43:78

Submitted: September 17, 2020

Accepted: December 7, 2020

Proofs received from author(s): March 9, 2021 